\title{
UMA DEVIDA HOMENAGEM AO PROFESSOR E AMIGO CARLOS MAGNO SADY VALADARES (in memorian)
}

Fábio Merçon Lincoln Tavares Silva

Dedicamos este número inaugural da Revista e-Mosaicos a um parceiro cujas atuações ainda nos deixam saudades. Não tomamos isso como desalento, pois os "do bem" deixam legados que procuramos seguir e melhorar.

Parceiro, companheiro, cúmplice.... Carlos Magno, com esse nome, o que esperar? Uma pessoa cuja química, desculpem a brincadeira, tornava fácil fazer amigos. Bom ouvinte, prestativo, compassivo, sem tempo para discriminar, também sem tempo a perder, prático. Alguém que mesmo cansado parecia, ao final, bem humorado. Este foi o Carlos, para alguns Magno, para outros Carlinhos, que conhecemos no CAp e na UERJ. É a ele que dedicamos, mesmo que com atraso, esta primeira edição da revista eletrônica do Instituto de Aplicação Fernando Rodrigues da Silveira. Quando pensamos como seria abrir uma revista eletrônica..., veio a sua imagem. Nome que sempre lembrávamos quando precisávamos editar nossos materiais ou produzir os eventos do CAp. Eventos de todo porte. Por vezes quase o enlouquecíamos, mas ele nos dava prazos que nossa discordância nunca conseguia apressar, com seu jeito de fazer o melhor. Ele nos convencia a esperar e, ao final, nós nos convencíamos que ele sabia o que estava fazendo. Alem disso, o Carlos sempre foi uma pessoa simples, direta, mesmo quando nós mesmos não sabíamos o que queríamos. Com toda sua paciência o parceiro ia orientando-nos, assim como o fazia com seus estudantes. A arte da docência exercida com decência e paciência. Com toda a incompletude em defini-lo, assim tentamos reaproximá-lo.

Carlos Magno teve sua vida ligada à UERJ, passando de professor a aluno. Nessa universidade ele se graduou engenheiro químico e químico licenciado, foi professor contratado do Instituto de Química e no CAp, culminando com seu ingresso como professor efetivo a partir de 1997.

No CAp, além das aulas para as turmas da Educação Básica, Carlos Magno foi chefe e 
subchefe do Departamento de Ciências da Natureza. Na mudança para a sede no Rio Comprido, reativou as aulas práticas no laboratório de Química e foi justamente esse projeto que, em 1998, foi premiado em 20 lugar no concurso "Experiências bem Sucedidas no Ensino Médio", realizado no "Fórum do Ensino Médio do Estado do Rio de Janeiro", promovido pelo Centro de Ciências do Estado do Rio de Janeiro (CECIERJ). O estudo das atividades de laboratório como recurso didático no ensino de Química tornou-se uma linha de pesquisa entre os professores de Química do CAp, o que proporcionou a apresentação de trabalhos em congressos e a publicação em revistas científicas. Destes eventos, destacam-se os Simpósios promovidos pelo CAp, dos quais Carlos Magno foi o responsável pela edição e produção dos anais em meio digital.

Em uma de suas últimas atividades ligadas ao laboratório, fez parte da equipe dos projetos submetidos à FAPERJ e à FINEP, os quais proporcionaram o fomento necessário para as obras de ampliação e reforma dos laboratórios ligados às ciências da natureza.

Esperamos que a produção que se segue e que os números posteriores façam jus ao amigo, profissional e grande mestre, Carlos Magno. 